Georgetown University Law Center

Scholarship @ GEORGETOWN LAW

2014

\title{
Some Thoughts on the Fundamentals of an Evidence Code From the U.S. American Perspective
}

Paul F. Rothstein

Georgetown University Law Center, rothstei@law.georgetown.edu

This paper can be downloaded free of charge from:

https://scholarship.law.georgetown.edu/facpub/1410

http://ssrn.com/abstract=2534609

This open-access article is brought to you by the Georgetown Law Library. Posted with permission of the author. Follow this and additional works at: https://scholarship.law.georgetown.edu/facpub

Part of the Courts Commons, Criminal Law Commons, Criminal Procedure Commons, and the Evidence $\underline{\text { Commons }}$ 


\section{SOME THOUGHTS ON THE FUNDAMENTALS OF AN EVIDENCE CODE}

FROM THE U.S. AMERICAN PERPECTIVE

Paul Rothstein

(Georgetown Law)

The subject of Evidence is the study of the rules regulating the proof of facts in the judicial trial of lawsuits, including the regulation of inferences that may be drawn from facts. In the U.S., functions are usually divided between a judge and a jury. The judge decides whether evidence is admissible and for what purposes. The jury determines what admissible evidence to believe, what it weighs, and what inferences to draw, except where inferences may be limited by a rule or ruling conveyed to the jury by a judicial instruction. The juror's task is to decide what the true facts of the case are and apply to them the tort law, contract law, criminal law, property law, family law, antitrust law, or other governing law, that the judge furnishes them. We have some trials without a jury. In them, the judge performs the functions of both judge and jury.

In the U.S. American trial system proof mainly consists of live witnesses presented in open court under oath before the judge, jury, and parties, subject to perjury laws. Cross-examination of the witnesses in that setting is the principal (though not the only) form of testing their reliability. It is for these reasons that we have a rule against hearsay (second-hand reporting in court of what someone has said outside of court).

The body of evidence rules is made up of individual filters, filtering out evidence for different reasons. An item of evidence must survive all the filters (or "hurdles" as they are sometimes called).

I. Why Regulate Evidence?

1. Open System vs. Regulated System

2. Concessions to the Shortness of Life

3. Human Fallibility

II. The Four Pillars of Evidence Regulation
A. Relevancy
B. Counterweights to Relevancy
C. Hearsay
D. Privilege 
III. Structure: What Prescriptions Governing Evidence Should Any Practical Dispute-Resolving System Have?
A. Relevance Provisions (Factoring in Counterweights)
B. Reliability Provisions
C. Social Policy Provisions or Components of Other Rules (Is Truth the only Concern?)
D. Procedural Provisions

1. Rules of the Road: How to Do It

2. Shortcuts Instead of Evidence (Judicial Notice, Presumptions, Burdens)

IV. Codification vs. Ad Hoc Judge-Made Rules or Rulings

A. To Codify or Not to Codify, That is the Question

Plusses of Codification:

1. Uniformity-All Judges Shooting for Same Target

2. Predictability (Why important)

3. Focus for Training-Practitioners, Law Students

4. Easy Findability-All in One Place

Minuses:

1. Tying Judges Hands

2. Drafters Can't Foresee Everything

Trick is to find just the right balance-not too rigid, not too flexible-like the 3 bears. Never going to get it exactly right, but may be better than uncodified. A process of continual perfecting will be needed.

B. Parameters of Codification: Complete vs. Incomplete Codification; Mechanisms for Evolution and Change

1. Role of Past and Future Case Law Under a Codification

a. More Flexibility Desirable in Certain Areas?

Privilege?

Hearsay? 


\section{Amendment}

C. Institutional Competency. Whom Should the Code Trust Most: Judge? Jury (if there is a separate fact-finder)? Lawyers?

1. Broad Admissibility?

2. Broad Discretion?

3. Form of Prescriptions
a. Standards?
b. Guidelines?
c. Rules?

\section{Different for Different Areas?}

5. The Relationship of Judicial Comment \& Rule Strictness (if fact-finder is separate)

V. Whom Should the Code be Addressing? Who is the Audience? (Comprehensibility, Readability, Language Choice)
A. Judges?
B. Lawyers?
C. Average Citizens?
D. Comparative Sophistication of These Audiences

VI. Effect of a Code on Appeals

VII. Some Likely Critical Areas
A. Expert Testimony
B. Character
C. Hearsay
D. Privileges
E. Lay Opinion
F. Electronic Evidence

VIII. Special Problems 
A. Should Civil and Criminal Evidence Regulation Be the Same? In All Areas?

B. The Role of Diverse Cultural Expectations

C. Cross Boarder Commerce and Foreign Abilities and Expectations

IX. Mechanics: Special Considerations

A. The Principal Categories of Evidence (Witnesses, Objects/Exhibits):

1. Testimonial Evidence (i.e., reports of facts)
a. Witnesses
b. Documents
c. Recordings

2. Real Evidence (Things)
a. Weapons
b. Contracts and Deeds
c. Narcotics

3. Representational Evidence

a. Charts, Models, Maps

b. Demonstrations

c. Experiments

d. Computer Simulations

B. Categories of Proof (by Method of Persuasion):

1. Direct

2. Circumstantial 